\title{
FACTORS INFLUENCING VALUE-ADDITION AGRICULTURAL CHOICE WITHIN SMALLHOLDER FARMING AGRIBUSINESSES OF GAUTENG PROVINCE IN SOUTH AFRICA
}

\author{
Tumiso Melembe ${ }^{\bowtie}$, Grany Mmatsatsi Senyolo ${ }^{1}$, Victor Mbulaheni Mmbengwa ${ }^{2}$
}

${ }^{1}$ Tshwane University of Technology, South Africa

${ }^{2}$ National Agricultural Marketing Council, South Africa

\begin{abstract}
This paper investigated factors influencing value addition agricultural choices of smallholder farming agribusinesses in the Gauteng Province, South Africa, using the Ordinary Least Squares regression model. The study used randomly sampled data collected from 102 smallholder farmers by the National Agricultural Marketing Council and the Gauteng Department of Agriculture and Rural Development. Four types of value addition were identified, namely postharvest, food preservation, milling, and post-slaughter. The results revealed that the number of people in the household, permanent workers, and access to training influences smallholder farmers' choice of post-harvest, food preservation, and post-slaughter value addition. Besides, milling value addition is influenced by the size of the farm, grain, and livestock production, together with access to information and training. These results call for government intervention in promoting agro-processing and value addition activities to encourage farmer participation, income generation, and poverty alleviation, thus improving the farmers' livelihoods.
\end{abstract}

Keywords: agro-processing, ordinary least squares, smallholder farmers, value addition, Gauteng

\section{INTRODUCTION}

Recently, the practice of value addition has gained prominence by making it possible to enhance and stabilise farm revenues, rejuvenating primary production in farming and improving rural economies (Roy et al., 2013). Value addition agriculture is a process involving product transformation, aiming to improve existing products (United States Department of Agriculture, 2010). This provides rural communities with enhanced jobs and opportunities for a new life, as well as expanding the manufacturing structure of agricultural businesses and increasing the farmers' economic stability while enabling them to enter niche markets (Evans, 2006; Bisht et al., 2020).

Demographics, commodity characteristics, and strategic agribusiness objectives determine value addition agriculture (Ngore, 2010). Socio-economic attributes are historical variables resulting from pressures exerted on the enterprise by the farmer's other practices, duties, and inherent human nature (Beyene, 2014). Market factors are elements of general market environments outside the farmer's influence, which affect his or her farming enterprise (Khapayi and Celliers, 2016). Ngore (2010) assumed that value addition improves agribusiness income. Holton (2006) and Abend (2018) indicated that choice involves decision making; others showed choice in agriculture as a process designed to provide agricultural producers with a strong foundation for consistently making good decisions in an incredibly challenging and changing competitive environment (Parsons, 2018).

\footnotetext{
凶Tumiso Melembe, Tshwane University of Technology, Department of Crop Sciences, South Africa, e-mail: tumisomelembe@ gmail.com; https://orcid.org/0000-0001-6746-0237
} 
For smallholder farmers to be integrated into the agribusiness value chains, the concern relating to inclusion emerges from the businesses' fear of favouring companies over smallholder farmers. This observation implicates the level of empowerment of smallholder farmers in the business relations with big players in the value chains, "the actual terms under which people are included, whether it is beneficial for smallholder farmers to be included in a value chain" (Schouten and Vellema, 2019). Ngore (2010) reports that increasing sales and profits are the primary goals behind the smallholder farmers' decision to take advantage of value addition. Sales need to be improved to avoid post-harvest losses from perishability since the businesses lack modern storage facilities, which makes them prone to losses related to perishability during low demand periods.

According to Dube et al. (2018), strong linkages between agriculture and agro-processing include the manufacturing and tertiary sectors of South Africa's economy. The growth of the agro-processing industry stimulates agricultural growth by creating new output markets and increasing farmers' incomes, enabling investment in land and inputs to improve productivity (ACET, 2017). Within the broader economy, the growth of agriculture and agro-processing value chains has a significant positive impact on other sectors in the economy through linkages to packaging and logistics, as well as retail linkages between agriculture and agroprocessing value chains, which present opportunities for growing employment. The Food and Agriculture Organization of the United Nations (FAO) noted that a structural transformation of agricultural systems requires that such systems become more productive and capital intensive to be better integrated with other economic sectors through markets (FAO, 2015). This would form alliances with companies producing packaging.

High levels of unemployment, primarily among the poor people in rural areas, remains a core challenge of the South African economy. The International Trade Administration Commission of South Africa (ITACSA) attested that natural resource value addition is directly correlated with job creation (ITACSA, 2016). The foodprocessing sector, a major manufacturing employer in South Africa, has shown real growth over time (Nhundu et al., 2017). Zalk (2017) and indicated high levels of fixed investments driven towards increasing returns, such as value addition. Although there has been growth within the agro-processing industry, a few sizeable leading food companies still control the value addition markets (Dube et al., 2018). Value addition requires infrastructure. The South African government's spending on agriculture has declined since the 1990s, and most of the infrastructure is privately funded (Liebenberg, 2013). The largest market for processed foods in SADC is South Africa, specifically the Gauteng Province (Paremoer, 2018). According to Mapiye et al. (2007) and Jayne et al. (2014), the attempts to transform the existing agricultural primary commodities have been limited, regardless of development efforts undertaken in most rural communities. Thindisa (2014) reported that smallholder agribusinesses should have higher revenues and become profitable through value addition activities. This investigation aimed to determine socio-economic factors influencing value addition agricultural choices for smallholder farming enterprises in the Gauteng Province.

\section{DETERMINANTS OF SMALLHOLDER FARMER VALUE ADDITION}

Value addition choices of smallholder farmers could be altered or impaired both due to the farmers' intellectual capacity and external factors (Etwire et al., 2013). Thindisa (2014) showed that cognitive skills such as farmer history, education level, previous market experience, and agricultural training could impact value addition, and external factors such as socio-economic factors and institutional services may influence it as well.

Formal training is essential, but agribusiness does not explicitly need such training as senior farmers with better training and experience can often transfer their skills to younger ones (Werquin, 2010). Formal education allows one to understand, predict, recognise and address business needs (Department of Agriculture Forestry and Fisheries, 2008). Education has been found to improve capabilities in risk-taking and capital mobilisation while reducing confusion in business management (Organization for Economic Co-operation and Development, 2018). This allows farmers to select the correct goods for value addition business, have the highest number of staff and achieve higher projected revenues (Ngore, 2010).

McElwee and Bosworth (2010) and Mbugua (2011) illustrated that age negatively affects the adoption of new technologies, with the assertion that young farmers implement innovations faster because they can seek 
new approaches to improve their businesses. Mmbengwa (2018) pointed out that male farmers believe that access to infrastructure can improve value addition, while female farmers believe the development of value chains and market access are significant in improving value addition.

Akudugu et al. (2012) and Abdulai and Huffman (2014) revealed dynamics of land size, showing that larger farm sizes are likely to influence the adoption of modern inputs. Mariano et al. (2012) asserted that institutional characteristics (access to training and information) influence the adoption of agricultural technologies. Based on evidence, Kruska et al. (2003) emphasized that value addition is affected by the opportunity to have resources, as well as the labour supply, technologies used, consumer demands, facilities available, and equipment hired. Wangu et al. (2020) report that a variety of socioeconomic attributes, including land size, farm income, number of crops, loan procurement, and the age and education level of the household heads, influence the decision to participate in value addition.

\section{METHODS}

\section{Research design}

The study was designed to be a quantitative study that yields descriptive and explanatory analysis. Hence, its research philosophy was based on a positivist paradigm. It was selected with the awareness of the inherent disadvantage of the quantitative research design (Queirós et al., 2017; Rahman, 2020). These potential weaknesses were mitigated by presenting the study results in the seminar, making the design itself a sequential explanatory mixed-method design.

\section{Sampling, data collection, and study area}

The investigation was undertaken across the four districts of the Gauteng Province, namely Sedibeng, City of Tshwane, City of Johannesburg, and the West Rand, utilising data collected from 102 smallholder farmers by the National Marketing Council for Agriculture (NAMC) and the Gauteng Department of Agriculture and Rural Development (GDARD) in 2017. According to STAT SA (2017), the Gauteng province had the lowest number of farmers in South Africa in 2017 (2291). A simple random sampling technique was used, extension agents from GDARD assisted in locating smallholder farmers. Only smallholder farmers who were willing to participate in the study were interviewed. Sampled smallholder farmers were involved in grain, vegetable, poultry, pig, and cattle farming in the Gauteng Province, South Africa.

\section{Data analysis}

This study used the ordinary least squares (OLS) technique. This approach is a linear regression modelling technique that can be utilised to model a particular response variable reported at least on a period scale. It can be used with complex interpretive variables and categorical interpretive variables coded accordingly (Hutcheson, 2011). The central element of this regression is that the interaction between a repeated response variable (A) and a repeated interpretive variable (B) can be interpreted at an elementary level using a best-fit line, where $\mathrm{A}$ is determined by $\mathrm{B}$, at least to some degree (Mahaboob et al., 2018).

The factor analysis (FA) method of extraction was utilised to identify smallholder farmers' choice of value addition patterns. FA made it possible to identify four value-addition patterns: post-harvest, food preservation, milling, and post-slaughter value addition.

This led to the linear function as follows:

$$
Y=\beta_{0}+\beta_{1} X_{1}+\beta_{2} X_{2}+\ldots \ldots+\beta_{14} X_{14}+\epsilon_{\mathrm{i}}
$$

Where:

$Y$ - is the value addition (post-harvest value addition, food processing value addition, milling value addition, post-slaughter value addition), $\beta_{0}-$ is the constant term, $\beta_{1} \ldots \beta_{14}-$ are the coefficients estimated, $X_{1}$, $X_{2} \ldots X_{14}-$ are responsive variables, and $\epsilon_{\mathrm{i}}$ is the error term, allowing two observations with identical values of $X$ 's to have different values for their outcome.

The model was utilised to calculate the econometric significance between the dependent variables (FA index value addition patterns) and several independent variables (socio-economic factors). Table 1 shows the list of variables used in the study.

\section{RESULTS AND DISCUSSION}

Table 2 shows the descriptive statistics results from continuous variables used in the study. The results show that a typical smallholder farmer in the Gauteng Province is 52 years old, with an average household size of six people. This means that smallholder farmers are 
Melembe, T., Senyolo, G. M., Mmbengwa, V. M. (2021). Factors influencing value-addition agricultural choice within smallholder farming agribusinesses of Gauteng Province in South Africa. J. Agribus. Rural Dev., 2(60), 183-191. http://dx.doi.org/10.17306/ J.JARD.2021.01374

Table 1. Variables on the OLS model

\begin{tabular}{|c|c|c|}
\hline Variables & Description & Unit \\
\hline \multicolumn{3}{|l|}{ Dependent variables } \\
\hline \multicolumn{3}{|l|}{ Post-harvest } \\
\hline Food preservation & Index from $\mathrm{FA}$ & Continuous \\
\hline \multicolumn{3}{|l|}{ Milling } \\
\hline \multicolumn{3}{|l|}{ Post-slaughter } \\
\hline \multicolumn{3}{|l|}{ Independent variables } \\
\hline \multicolumn{3}{|c|}{ Demographic characteristics } \\
\hline AGE & Age of the farmer & Years \\
\hline $\mathrm{AGE}^{2}$ & Age of the farmer squared & Continuous \\
\hline GEN & 1 if the farmer is male, 0 otherwise & Binary \\
\hline EDU & 1 if the farmer has high school education, 0 otherwise & Binary \\
\hline HHDSI & Number of household members & Number \\
\hline \multicolumn{3}{|l|}{ Farmer characteristics } \\
\hline PERMWKR & Number of permanent workers & Number \\
\hline LNDTNR & 1 if the land is owned by farmer, 0 otherwise & Binary \\
\hline FAEXP & Farmer's farming experience & Years \\
\hline FASI & Size of the farm & $\mathrm{Ha}$ \\
\hline CROPS & 1 if the farmer produces crops, 0 otherwise & Binary \\
\hline GRAINS & 1 if the farmer produces grains, 0 otherwise & Binary \\
\hline LIVESTOCK & 1 if the farmer produces livestock, 0 otherwise & Binary \\
\hline \multicolumn{3}{|c|}{ Institutional characteristics } \\
\hline TRNG & 1 if the farmer has access to training, 0 otherwise & Binary \\
\hline AGROINF & 1 if the farmer has access to information, 0 otherwise & Binary \\
\hline
\end{tabular}

Source: survey data, 2017.

Table 2. Descriptive statistics results from continuous variables used in the study $(n=102)$

\begin{tabular}{lcrrr}
\hline \multicolumn{1}{c}{ Variable } & Mean & Std. Dev. & Min & Max \\
\hline AGE & 52.352 & 14.246 & 20 & 80 \\
AGE $^{2}$ & 2941.80 & 1503.018 & 400 & 6400 \\
HHDSI & 5.85 & 2.973 & 1 & 20 \\
FASI & 70.216 & 273.126 & 1 & 2000 \\
FAEXP & 17.4 & 17.949 & 1 & 85 \\
PERMWKR & 1.59 & 2.309 & 1 & 16 \\
\hline
\end{tabular}

Source: survey data, 2017. likely to involve some family members in farming. On average, a smallholder farmer in the Gauteng Province occupies 70 hectares of land and has 17 years of farming experience. Regarding the farm size, this may indicate that farmers in the study area have access to land, but most of it is underutilised, with an average of roughly 2 permanent workers employed.

Table 3 shows descriptive statistics for a selected categorical variable in the study area. The results show that roughly $61 \%$ of the farmers are male while $39 \%$ are female. Regarding education, most of the farmers (54.9\%) have secondary/high school education while close to $20 \%$ have tertiary education. Less than $10 \%$ of 
Melembe, T., Senyolo, G. M., Mmbengwa, V. M. (2021). Factors influencing value-addition agricultural choice within smallholder farming agribusinesses of Gauteng Province in South Africa. J. Agribus. Rural Dev., 2(60), 183-191. http://dx.doi.org/10.17306/ J.JARD.2021.01374

Table 3. Descriptive statistics for the selected categorical variable $(n=102)$

\begin{tabular}{llcc}
\hline \multicolumn{1}{c}{ Variable } & \multicolumn{1}{c}{ Category } & Freq. & Percent \\
\hline GEND & Male & 62 & 60.78 \\
& Female & 40 & 39.22 \\
EDUC & No formal education & 10 & 9.80 \\
& Primary & 16 & 15.69 \\
& Secondary & 56 & 54.90 \\
& Tertiary & 20 & 19.61 \\
LANDT & Own land & 48 & 47.06 \\
& Does not own land & 54 & 52.94 \\
TRAIN & Yes & 13 & 13.13 \\
& No & 86 & 86.87 \\
AGRINF & Yes & 21 & 20.59 \\
& No & 81 & 79.41 \\
ENTERPRISE & Grain & 11 & 10.78 \\
& Crops & 21 & 20.59 \\
& Livestock & 70 & 68.63 \\
\hline
\end{tabular}

Source: survey data, 2017.

the farmers have no formal education in the study area. Although land is a critical factor in agriculture, the results show that less than $50 \%$ of the farmers own farms. Besides, $10.78 \%, 20.59 \%$, and $68.63 \%$ of farmers produce grains, crops, and livestock, respectively. More than $80 \%$ of the farmers do not have access to training and agro-processing information.

\section{Variance inflation factor correlations}

Table 4 illustrates the variables from the highest moderate correlation to the lowest. According to Chappelow (2018), a high variance inflator factor (VIF) indicates the associated independent variable is positively correlated with the other variables.

The farming experience was the variable that had a more significant correlation with the other variables; the least correlated variable was gender. Also, the mean VIF was $<5(1.4)$, suggesting no collinearity problems with variables because they were not strongly correlated; that is, the results would not be skewed, and the model could include all variables under consideration.
Table 4. Predictor variables correlations

\begin{tabular}{lll}
\hline \multicolumn{1}{c}{ Variable } & VIF & 1 /VIF \\
\hline FAEXP & 1.83 & 0.546 \\
AGE & 1.59 & 0.630 \\
CROPS & 1.53 & 0.653 \\
TRNG & 1.43 & 0.701 \\
PERMWKR & 1.36 & 0.737 \\
AGROINF & 1.34 & 0.745 \\
LIVESTOCK & 1.33 & 0.752 \\
HHDSI & 1.32 & 0.756 \\
GRAINS & 1.31 & 0.765 \\
EDU & 1.20 & 0.830 \\
FASI & 1.20 & 0.835 \\
LNDTNR & 1.19 & 0.841 \\
GEN & 1.14 & 0.877 \\
Mean VIF & 1.4 & \\
\hline
\end{tabular}

Source: survey data, 2017.

\section{Factors influencing smallholder farmers' choice of value addition}

Literature on the adoption of agricultural technology states that the characteristics of farm households determine the choice to implement innovations such as value-added solutions, farm businesses, and institutional features (Croppenstedt et al., 2003; Amsalu and De Jan 2007; Ememwa et al., 2008; Kaguongo et al., 2010; Tura et al., 2010; Ngombe et al., 2014). Table 5 shows the results on the determinants affecting the smallholder farmers' choice of value addition, estimated using the OLS model. The dependent variables were the value addition index generated using FA (Melembe et al., 2020). The remarkable $F$ value demonstrates that this Ordinary Least Squares method matches the data well. This means that collectively, the value addition choice was significantly influenced by the independent variables.

The negative estimated coefficient of household size (HHDSI) indicates a negative association between post-harvest value addition and household size. A unit increase in household size results in a decrease in the post-harvest value addition index of 0.085 points. This implies that larger households are less likely to 
Melembe, T., Senyolo, G. M., Mmbengwa, V. M. (2021). Factors influencing value-addition agricultural choice within smallholder farming agribusinesses of Gauteng Province in South Africa. J. Agribus. Rural Dev., 2(60), 183-191. http://dx.doi.org/10.17306/ J.JARD.2021.01374

Table 5. Determinants of smallholder farmer choices of value-addition

\begin{tabular}{|c|c|c|c|c|}
\hline Variables & Post-harvest & Food preservation & Milling & Post-slaughter \\
\hline AGE & 0.012 & 0.011 & 0.016 & -0.012 \\
\hline $\mathrm{AGE}^{2}$ & 0.000 & 0.000 & 0.000 & 0.000 \\
\hline GEN & 0.063 & -0.307 & 0.035 & -0.221 \\
\hline EDU & 0.081 & 0.248 & -0.042 & 0.211 \\
\hline HHDSI & $-0.085 * *$ & 0.008 & -0.018 & -0.001 \\
\hline PERMWKR & -0.048 & $0.178 * * *$ & 0.016 & -0.039 \\
\hline LNDTNR & -0.268 & -0.064 & -0.022 & 0.129 \\
\hline FAEXP & -0.008 & -0.003 & 0.009 & -0.002 \\
\hline FASI & 0.000 & 0.000 & $0.001 * *$ & 0.000 \\
\hline CROPS & -1.336 & 1.085 & -1.713 & -0.587 \\
\hline GRAINS & 0.274 & -0.026 & $0.128 * * *$ & -0.268 \\
\hline LIVESTOCK & -0.530 & -0.383 & $1.430 * * *$ & -0.080 \\
\hline TRNG & 0.461 & 0.371 & $0.876 * * *$ & $0.461 * *$ \\
\hline AGROINF & 0.015 & 0.066 & $0.507 * *$ & 0.282 \\
\hline CONS & -0.252 & -0.366 & -0.219 & $2.124 * * *$ \\
\hline $\mathrm{F}(21,80)$ & 1.75 & 2.14 & 3.46 & 7.82 \\
\hline Prob $>$ F & 0.0393 & 0.0083 & 0.0000 & 0.0000 \\
\hline Adj R-Squared & 0.3150 & 0.3594 & 0.4762 & 0.6723 \\
\hline Root MSE & 0.92997 & 0.89934 & 0.81324 & 0.64321 \\
\hline
\end{tabular}

Notes: $* * *, * *, *$ means significant at $1 \%, 5 \%$ and $10 \%$ levels, respectively.

Source: survey data, 2017.

undertake post-harvest practices as a value-added compared to smaller households. This result is consistent with the findings of Amentae et al. (2015) and Tadesse et al. (2018). This may also indicate that bigger households are less dependent on farming but instead engage in other economic activities. It was expected that large households would have a conclusive positive influence on the adoption of value addition by farmers. Another explanation of these findings could be that larger households in the Gauteng Province are less reliant on farming than on smaller households since they participate in other commercial activities due to Gauteng being South Africa's economic hub. Although agriculture may provide financial support for a certain number of family members, this also indicates that it is essential for larger families to seek opportunities in other sectors as a farm may be insufficient to meet their needs.
The results also show that the number of permanent workers (PERMWKR) is the only factor with a positive relationship with the food preservation value addition index. A unit increase in the number of permanent workers increases the food preservation value addition index of 0.178 points. The results imply that smallholder farmers with more permanent employees are more likely to preserve their produce. This concurs with the findings of the Food and Agriculture Organization of the United Nations (FAO), indicating that smallholder agribusinesses with more labour employed permanently had more potential to send products for processing and preservation (FAO, 2015).

Farm size (FASI) was positively associated with milling. This means that farmers with smaller lands would have less potential to engage in milling than farmers who have access to larger plots. Khoza et al. (2019) indicated 
that smallholder agribusinesses with large farm sizes are likely to diversify into value addition technology. The availability of more land encourages families to produce more and gives them the ability to achieve a surplus. Smallholder farmers producing grains (GRAINS) and livestock (LIVESTOCK) are more likely to mill. This could indicate that some livestock farmers produce their grains as animal feed through milling. The results highlight the importance of institutional factors - access to information (AGROINF) and access to training (TRNG) - in smallholder farming. Agribusinesses with access to value addition training are more likely to take part in both milling and post-slaughter value addition, while access to information only positively influences the choice of milling value addition. This concurs with a study by Tura et al. (2010), which asserted that training and access to extension or information are important factors determining the continued use of adopted technologies. Also, Ememwa et al. (2008) reported that institutional factors are the significant hurdles in production. However, Adzitey et al. (2018) reported that many smallholder farmers have inadequate skills and training to handle meat in informal meat markets.

\section{CONCLUSION AND RECOMMENDATIONS}

The primary aim of this study was to determine factors influencing the choice of value addition by smallholder farmers in the Gauteng Province, South Africa. Four types of value addition were identified, namely postharvest, food preservation, milling, and post-slaughter. The investigation revealed that the choice of post-harvest and food preservation value addition is influenced by the number of household members and the number of permanent workers, respectively. The choice of the milling value addition is influenced by the farm size, grain and livestock production, as well as access to information and training. Lastly, the choice of post-slaughter value addition is influenced by access to training by smallholder farmers. This brings one to the conclusion that smallholder farmers with training and more permanent staff chose food preservation and post-slaughter activities.

Furthermore, it was indicated that bigger households in the Gauteng Province have a chance to seek other economic activities, as Gauteng is South Africa's economic hub. This study recommends that smallholder farmers who produce grains and livestock need more access to training and information regarding value addition and agro-processing. From these findings, it is evident that the smallholder farmers' production capacity largely determines integration. The more affluent households are better positioned to benefit from the business initiative, while the more impoverished ones are excluded.

Policies to tackle the challenges faced by smallholder farmers about value addition should be put in place. Access to training and information on agro-processing or value addition will help smallholder farmers improve income and reduce food insecurity, improving their livelihoods. As the current study focused on the different value addition activities, it is recommended that research be carried out in different agricultural sector enterprises, with specific emphasis on the impact of the implementation of value addition policies.

\section{ACKNOWLEDGEMENTS}

The writers gratefully acknowledge GDARD and NAMC for the support and guidance provided for this project. The Postgraduate Scholarship from the Tshwane University of Technology is also recognised for financial support.

\section{REFERENCES}

Abdulai, A., Huffman, W. (2014). The adoption and impact of soil and water conservation technology: An endogenous switching regression application. Land Econ., 90(1), 26-43.

Abend, G. (2018). The limits of decision and choice. Theo. Soc., 47, 805-841.

ACET (African Centre for Economic Transformation). (2017). Agriculture, powering Africa's economic transformation. African Transformation Report 2017, Ghana.

Adzitey, F., Sulleyman, K.W., Mensah, S.S. (2018). Knowledge and practices of meat safety by meat sellers in the Kumasi Metropolis of Ghana. J. Food Sci. Technol., 7(2), 34-41.

Akudugu, M.A., Guo, E., Dadzie, S.K. (2012). Adoption of modern agricultural production technologies by farm households in Ghana: What factors influence their decisions? J. Biol. Agric. Health., 2(3), 1-13.

Amsalu, A., De Jan, G. (2007). Determinants of adoption and continued use of stone terraces for soil and water conservation in an Ethiopian highland watershed. Ecol. Econ., 61, 294-302. 
Melembe, T., Senyolo, G. M., Mmbengwa, V. M. (2021). Factors influencing value-addition agricultural choice within smallholder farming agribusinesses of Gauteng Province in South Africa. J. Agribus. Rural Dev., 2(60), 183-191. http://dx.doi.org/10.17306/ J.JARD.2021.01374

Beyene, H.G. (2014). Socio-economic factors as causes and remedies for conflict of the San community in Platfontein. J. Transdiscip. Res. South Afr., 10(4), 99-119.

Bisht, I.S., Rana, J.C., Ahlawat, S.P. (2020). The future of smallholder farming in India: Some sustainability considerations. Sustainability, 12, 3751.

Chappelow, J. (2018). Variance inflation factor definition. Investopedia. https://www.investopedia.com/terms/v/variance-inflation-factor.asp

Croppenstedt, A., Demeke, M., Meschi, M.M. (2003). Technology adoption in the presence of constraints: The case of fertilizer demand in Ethiopia. Rev. Dev. Econ., 7(1), 58-70.

DAFF (Department of Agriculture, Forestry and Fisheries). (2008). Evaluation of agricultural education and training curricula in South Africa. DAFF Report, South Africa.

Dube, S.C., das Nair, R., Nkhonjera, M., Tempia, N. (2018). Structural transformation in agriculture and agro-processing value chains. Centre for Competition, Regulation and Economic Development, Working paper 8. University of Johannesburg, South Africa.

Ememwa, L., Nungo, R.A., Obiero, H.M., Ndolo, P.J. (2008). Challenges and Experiences in Transfer of post-harvest Technologies to Farming Communities in western Kenya: A case of cassava and sweet potato processing. In Biennial scientific conference and 3rd agricultural forum, 10th-13th November.

Etwire, P.M., Dogbe, W., Wiredu, A.N., Marty, E., Etwire, E., Owusu, R.K., Wahaga, E. (2013). Factors influencing farmer's participation in agricultural projects: The case of agricultural value chain mentorship project in the Northern Region of Ghana. J. Econ. Sust. Dev., 10(4), 36-43.

Evans, E. (2006). Value added agriculture: is it right for me? Gainesville: Florida Cooperative Extension Service, Institute of Food and Agricultural Sciences, University of Florida.

FAO (Food and Agriculture Organization of the United Nations). (2015). The economic lives of smallholder farmers: An analysis based on household data from nine countries. Rome.

FAO (Food and Agriculture Organization of the United Nations). (2017). The future of food and agriculture: Trends and challenges. Rome.

Holton, R. (2006). The art of choice. Philos. Imp., 6(3), 1-15.

Hutcheson, G.D. (2011). Categorical Explanatory variables. J. Model. Manag., 6(2), 225-236.

ITACSA (International Trade Administration Commission of South Africa). (2016). Agro-processing markets and related trade trends: Opportunities and challenges for South Africa. Report.

Jayne, T.S., Chamberlin, J., Headey, D.D. (2014). Land pressures, the evolution of farming systems, and development strategies in Africa: A synthesis. Food Polic., 48, 1-17.
Kaguongo, W.P., Nganga, N.M., Muthoka, N., Muthami, F., Maingi, G. (2010). Seed potato subsector master plan for Kenya (2009-2014). Seed potato study sponsored by GTZ-PSDA, USAID, CIP and Government of Kenya. Ministry of Agriculture, Kenya.

Khoza, T.M., Senyolo, G.M., Mmbengwa, V.M., Soundy, P. (2019). Socio-economic factors influencing smallholder farmers' decision to participate in agro-processing industry in Gauteng Province, South Africa. Cogent Soc. Sci., 5(1), 1664193.

Kruska, R.L., Reid, R.S., Thornton, P.K., Henninger, N., Kristjanson, P.M. (2003). Mapping livestock-oriented agricultural production systems for the developing world. Agric. Syst., 77, 39-63.

Liebenberg, F. (2013). South African agricultural production, productivity and research performance in the 20th century. University of Pretoria, South Africa.

MacDonald, R., Reitmeier, C. (2017). Understanding Food Systems: In agriculture, food science and nutrition in the United States ( $1^{\text {st }}$ ed., pp. 179-225).

Mahaboob, B., Venateswarlu, B., Narayana, C., Ravisanker, J., Balasiddamuni, P. (2018). A treatise on ordinary least squares estimation of parameters of linear model. Int. J. Eng. Technol., 7(10), 518-522.

Mapiye, C., Chimonyo, M., Muchenje, V., Dzama, K., Marufu, M.C., Raats, J.G. (2007). Potential for value-addition of Nguni cattle products in the communal areas of South Africa: A review. Afr. J. Agric. Res., 2(10), 488-495.

Mariano, M.J., Renato, V., Euan, F. (2012). Factors influencing farmers' adoption of modern rice technologies and good management practices in the Philippines. Agric. Syst., 110(C), 41-53.

Mbugua, F. (2011). An analysis of factors influencing adoption of the recommended maize technology's package in Makuyu Division, Murang'a South District, Kenya. Doctoral dissertation. Kenya: Kenyatta University.

McElwee, G., Bosworth, G. (2010). Exploring the strategic skills of farmers across a typology of farm diversification approaches. J. Farm Manag., 13(12), 819-838.

Melembe, T., Senyolo, G.M., Mmbengwa, V.M. (2020). Patterns of smallholder farmers' choice of value addition in Gauteng Province, South Africa. J. Human Ecol., 70, 9-14.

Mmbengwa, V.M., Khoza, T.M., Rambau, K., Rakuambo, J. (2018). Assessment of the participation of smallholder farmers in agro-processing industries of Gauteng Province. Int. J. Sust. Dev., 11(20), 12-18.

Mukarumbwa, P. (2017). Determinants of smallholder vegetable farmers' participation on post-harvest practices and market access: evidence from Mashonaland East Province of Zimbabwe. Doctoral dissertation. University of Fort Hare, South Africa. 
Ngombe, J., Kalinda, T., Tembo, G., Kuntashula. E. (2014). Econometric analysis of the factors that affect adoption of conservation farming practices by smallholder farmers in Zambia. J. Sust. Dev., 7(4): 124-139.

Ngore, P.M. (2010). Evaluation of factors influencing value addition by butchery agribusiness in Igembe North District, Kenya. Master Dissertation. Egerton University, Kenya.

Nhundu, N., Paelo, A., Thosago, M., Vilakazi, T. (2017). Growth and strategies of large and leading firms - Food production and processing sector assessment. Centre for Competition, Regulation and Economic Development. Working Paper 10. University of Johannesburg, South Africa.

OECD (Organization for Economic Co-operation and Development). (2018). The future of education and skills, Education 2030. Position Paper.

Paremoer, T. (2018). Regional value chains: exploring linkages and opportunities in the agroprocessing sector across five SADC countries. CCRED Working Paper No. 4.

Parsons, P. (2018). Smart choices in agriculture. Cornhus. Econ., 402, 472-1911.

Queirós, A., Faria, D., Almeida, F. (2017). Strengths and limitations of qualitative and quantitative research methods. Eur. J. Educ. Stud., 3(9), 369-386.

Rahman, M.S. (2020). The advantages and disadvantages of using qualitative and quantitative approaches and methods in language "testing and assessment" research: A literature review. J. Edu. Learn., 6(1), 102-112.

Roy, R., Shivamurthy, M., Radhakrshna, R.B. (2013). Impact of value addition training on participants of farmers' training institutes. World Appl. Sci. J., 22(10), 1401-1411.

Schouten, G., Vellema, S. (2019). Partnering for inclusive business in food provisioning. Curr. Opin. Env. Sust., 41, 38-42.
Tadesse, B., Bakala, F., Mariam, L.W. (2018). Assessment of post-harvest loss along potato value chain: the case of Sheka zone, South West Ethiopia. Agric. Food Sec., 7(1), 18.

Thindisa, L.M.V. (2014). Participation by smallholder farming entrepreneurs in agro-processing activities in South Africa. Masters Dissertation. University of Witwatersrand, South Africa.

Tura, M., Aredo, D., Tsegaye, W., Rovere, R., Kassie, G., Mwangi, W., Mwabu, G. (2010). Adoption and continued use of improved maize seeds: Case study of Central Ethiopia. Afr. J. Agric. Res., 5(17), 2350-2358.

USDA (United States Department of Agriculture). (2010). A national information resource for value added agriculture. USDA Report, United States of America.

Wangu, J., Mangnus, E., van Westen, A.C.M. (2020). Limitations of inclusive agribusiness in contributing to food and nutrition security in a smallholder community. A case of mango initiative in Makueni County, Kenya. Sustainability, 12(14), 1-23.

Werquin, P. (2010). Recognition of non-formal and informal learning: Country practices. Organization for Economic Co-operation and Development Report.

Wildman, M.L., Torres, R.M. (2002). Factors influencing choice of major in agriculture. North Am. Coll. Teach. Agric., 46(3), 4-9.

Zalk, N. (2017). Multi-year expert meeting on enhancing economic environment at all levels in support of inclusive and sustainable development, and the promotion of economic integration and cooperation. Department of Trade and Industry Report, South Africa. 